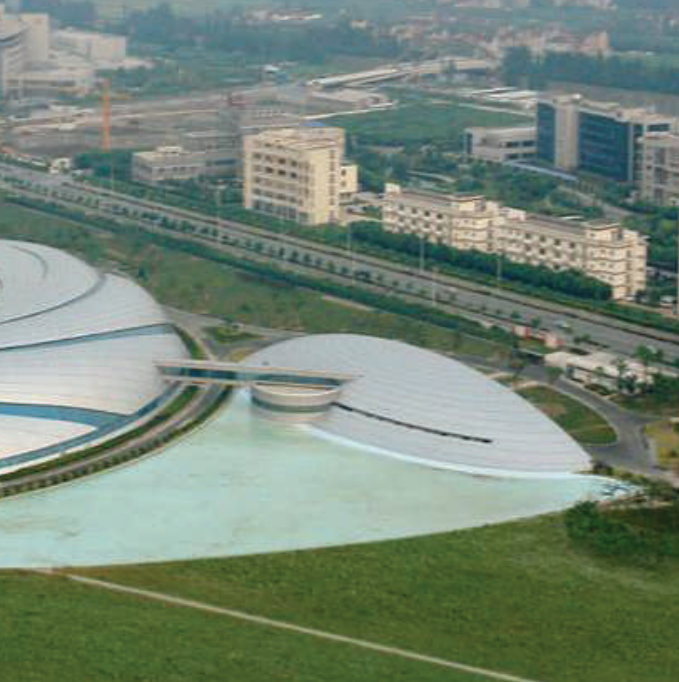

X-rays. For many Chinese scientists, who have lacked either the funding or the visas to use facilities abroad, the SSRF is a chance to see what cutting-edge synchrotrons can do.

Zhao hopes that the investment in worldclass facilities such as the SSRF will give Chinese scientists more reason to keep their research programmes in China, or to return from abroad. Indeed, Guo-Yuan Yang, a neurosurgeon who studied the mechanisms of cerebrovascular diseases for 20 years in the United States, says that he has returned to China in part because of the SSRF. Now based at Shanghai Jiao Tong University, he says the beams will allow him to examine, for example, real-time changes in small blood vessels seen in arteriovenous malformation - a circulatory disorder. "In the past we had to sacrifice animals, but here we can follow them day by day," he says.

At another SSRF beamline dedicated to $\mathrm{X}$-ray absorption fine structure (XAFS), which is particularly suited to analysing the atomic structure of liquids, a group led by Guozhong Wu of the Shanghai Institute of Applied Physics is looking at the iron ion content in an ionic liquid to investigate its catalytic properties. The institute's Yuying Huang, who is in charge of the beamline, says 60 research groups from China have already requested time. "We are asking the government to build another [XAFS] line," he says.

Lili Chen of the Shanghai Institute of Materia Medica, who is using a beamline to look at the structures of complex proteins related to diabetes and other diseases, says there are already applications to use 7,000 hours of time on that beamline in 2010 - almost twice as much as has been budgeted for.

With demand that high, says Winick, "it's going to be a zoo here in a year".

David Cyranoski

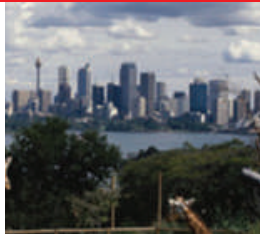

FLU MONITORING

Zoos help track the spread of pandemics.

www.nature.com/news

\title{
Even big societies feel the pinch
}

The American Chemical Society (ACS), the world's biggest scientific society, is feeling the effects of the global economic downturn.

On 28 April, six months after tightening its belt a first notch, the society laid off 56 people, $3 \%$ of its employees. New employment will be frozen indefinitely, and the society has capped its contributions to medical insurance for retired employees and cut back on other expenses such as travel.

The ACS, based in Washington DC, blames its financial problems on the falling values of its investments, as well as falling revenue from its publications, which include the Journal of the American Chemical

Society and Chemical \& Engineering News, as subscribers move from print to online-only deals. Its reserves were US\$60 million at the end of 2008, compared with $\$ 212$ million the year before.

\section{"The whole publishing enterprise has entered a} momentous time."

were laid off. The publications division generates more revenue than any other division of the society apart from the Chemical Abstracts Service, a fee-based database of chemical information and suite of tools to search it.

According to notes taken by a laid-off employee at a meeting of the publications division on 30 January, the ACS earns about $\$ 500$ million annually in revenues, with $29 \%$ from the publications division. In 2008, revenue growth in the division was just $2.5 \%$, down from $7-10 \%$ a year.

Ruskin says that the layoffs were strategically chosen. "The whole publishing enterprise has entered probably one of the more momentous times in its history: we are now moving from print to electronic," he says. "Part of what we are doing with the reduction is responding to that evolution."

Even vocal critics of the society's opposition to open-

The society has also posted a \$36.5-million bond in a lawsuit it recently lost against the chemical-information company Leadscope in Columbus, Ohio. It had argued that the founders of Leadscope - former employees of the society — had used intellectual property belonging to the society. The ACS plans to appeal against the decision, but if it loses, it may owe that $\$ 36.5$ million plus interest. According to Glen Ruskin, director of the ACS office of public affairs, the possible outlay is "not having any impact on our financials at this point, nor did it figure in the actions we took on Tuesday [28 April]".

Of the 56 layoffs, 40 were in the publications division. Ten staff members at Chemical \& Engineering News and the entire reporting team at Environmental Science \& Technology

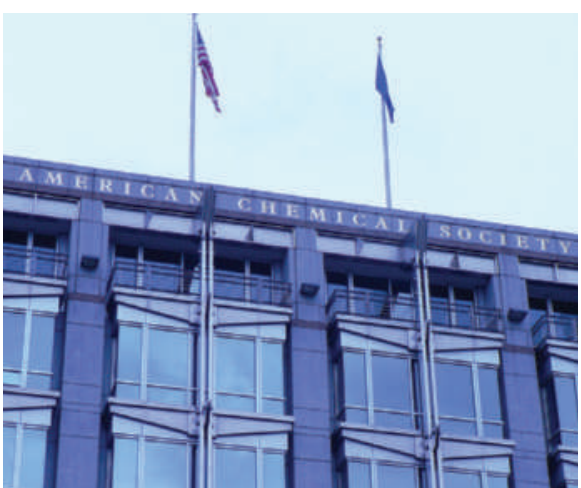

Hit by the downturn and the online revolution. access publishing aren't delighting in its financial woes. Peter Murray Rust of the University of Cambridge, UK, whose blog covers open-access chemical information, says that he wishes the society well. "I have not been a supporter of many of [its] policies," he says, "but I would say that we absolutely need national scientific societies."

Other societies are also seeing the value of their portfolios decline. "Our investments fared about as well as anyone's," says Mark Hernick, director of finance at the American Geophysical Union, also based in Washington DC. "Most investments lost 20 to $40 \%$ of their value last year alone, and we were in that category." He says that his society is not planning staffing reductions.

Richard Pike, chief executive of the London-based Royal Society of Chemistry, says, "Our reserves are hit, but we are in a somewhat better condition than some others - we had a good year ending in 2008". The UK society is actually adding staff, Pike says, mostly in its publications and membership divisions.

Ruskin says that he hopes ACS members won't notice any change in services provided by the society. "All the things that we provide to them are considered essential," he says. "How do we continue to provide that in a manner that is sustainable?" Emma Marris 


\section{Russia shifts stance on climate-change policy}

Russia's government has quietly made a dramatic change to its policy on climate change, accepting that anthropogenic global warming poses severe risks and requires immediate action to limit carbon emissions.

"Russia's diplomatic approach to [December's scheduled climate talks in] Copenhagen was until now just one big silence," says Kristin Jørgensen, a climate-policy expert with Bellona, an environmental watchdog based in Norway that has a network of activists in Russia. "This is a totally surprising move. There were no hearings, no stakeholder discussion, no public debate - just nothing."

Policy analysts believe that the new climate 'doctrine', adopted in late April, marks a historic turning point. Principally a position statement, the doctrine also outlines a checklist of key climate actions. It follows a February assessment report compiled by leading Russian climate scientists, which was presented to the Russian cabinet on 23 April. For a longer version of this story, see http://tinyurl.com/q2tyjn.

\section{United States urged to boost global health funds}

An expert committee convened by the US Institute of Medicine has called for the country to increase investment in global health initiatives to $\$ 15$ billion per year by 2012 .

Earlier in May President Barack Obama asked Congress to dedicate an average of $\$ 10.5$ billion per year over the next six years to a global health initiative, with $\$ 8.5$ billion of that funding dedicated to the HIV/AIDS programme PEPFAR (see Nature 457, 254-256; 2009).

But the committee, which included former National Institutes of Health head Harold Varmus, recommended that $\$ 13$ billion be invested in fulfilling healthrelated Millennium Development Goals put forward by the United Nations, with another $\$ 2$ billion for combating injuries and non-communicable conditions, such as heart disease. In addition, it advised that an inter-agency global health committee be created and located in the White House to coordinate such activities.

\section{JOHN MADDOX}

A memorial meeting to celebrate the life of Sir John Maddox, the editor of Nature for many years, will be held on Friday 5 June 2009 at 6 p.m., followed by a reception, at The Royal Institution, 21 Albemarle Street, London W1S 4BS.

Those wishing to attend should notify Diane Kempinski at Nature, d.kempinski@nature.com. Places are limited.

\section{THAT FOSSIL FRENZY IN FULL}

"This specimen is like finding the lost ark for archaeologists. It is the scientific equivalent of the Holy Grail."

Jørn Hurum, University of Oslo, at the New York press unveiling of a 47-million-year-old fossil, christened Ida (pictured), last week.

\section{"[It is] like the eighth wonder of the world."}

Jens Franzen, Natural History Museum of Basel, Switzerland, who was involved in analysing the fossil.

"Any pop band is doing the same thing. We have to start thinking the same way in science."

Hurum justifies the attention.

"There was a TV company involved and time pressure. We've been pushed to finish the study; it's not how I like to do science."

Hurum's co-worker Philip Gingerich of the University of Michigan, Ann Arbor, reflects.

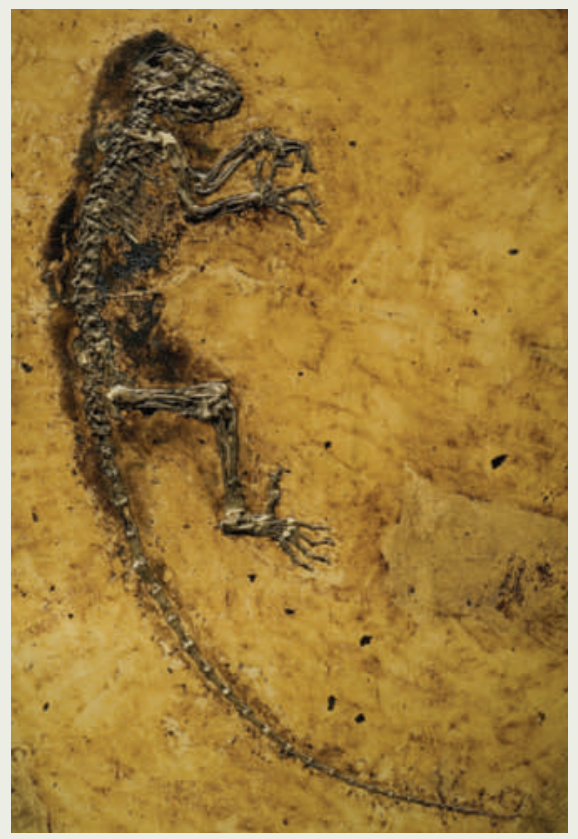

For more on Ida see http://tinyurl.com/idafossil and Editorial, page 484.

Sources: The Wall Street Journal, The New York Times, BBC, Fox News, The Guardian

\section{UK geographers vote against large expeditions}

Members of London's Royal Geographical Society have thrown out a resolution to resume large exploratory expeditions. Campaigners say that the vote highlights growing division within the world's biggest scholarly geographical society.

The society stopped organizing large expeditions such as open-ended explorations of rainforests, after reviews of research practices in 2001 and 2004 suggested that smaller, more focused projects were the best ways to tackle global problems such as climate change and the security of food and water. "Twenty-firstcentury geography, not nineteenth-century geography, is what we're talking about," says Gordon Conway, the society's president.

The resolution was defeated by 2,590 votes to 1,607 on 18 May. Supporters of the 'Beagle Campaign' that put forward the resolution say they will continue to advocate their cause. For a longer version of this story, see http://tinyurl.com/pbx929.

\section{Delays to satellite launches put GPS at risk}

Concern over the future performance of the US Global Positioning System (GPS) went up a notch last week as a government watchdog official warned that the US Department of Defense faced substantial challenges meeting its space-programme commitments.
A report from the Government Accountability Office (GAO) on 30 April had cautioned that new GPS satellites might not be launched in time to replace the ageing constellation that is currently in orbit. And on 20 May, Cristina Chaplain, GAO director of acquisition and sourcing, told the Senate committee on armed services that cost overruns of space programmes are part of the problem.

Dave Buckman, of the US Air Force Space Command, quickly replied on a Twitter feed that "GPS isn't falling out of the sky". Still, a temporary decline in performance might cause a problem for scientists who rely on GPS-positioned equipment that cannot be easily upgraded, such as low Earth-orbiting satellites, says Marek Ziebart, a space geodesy researcher at University College London.

For a longer version of this story, see http://tinyurl.com/gpsthreat.

\section{Corrections}

The News Feature 'The sleeping dragon' (Nature 459, 153-157; 2009) misstated the number of landslides thought to result from the 2008 Sichuan earthquake. It should have said that scientists have identified at least 15,000 resulting landslides and rock avalanches, and perhaps as many as 50,000 or more.

The News story 'Even big societies feel the pinch' (Nature 459, 17; 2009) cited incorrect information, provided by the American Chemical Society, that the society had already posted a \$36.5-million bond in a lawsuit it recently lost. The society expects the bond will be posted by the first week of June. 